\title{
1,5-Dimethyl-6H-pyridazino[4,5-b]carbazole, a 3-Aza Bioisoster of the Antitumor Alkaloid Olivacine
}

\author{
Norbert Haider* and Eddy Sotelo ${ }^{1)}$ \\ Institute of Pharmaceutical Chemistry, University of Vienna; Althanstraße 14, A-1090 Vienna, Austria. \\ Received July 1, 2002; accepted August 5, 2002
}

\begin{abstract}
A series of $b$-fused carbazoles structurally related to pyrido[4,3-b]carbazole-type alkaloids was prepared, utilizing the Diels-Alder reaction of 1-methylpyrano[3,4-b]indol-3(9H)-one with electron-deficient acetylenic dienophiles as the key step. The title compound (14) thus obtained in only four steps represents a new 3-aza ana$\log$ of the antitumor natural product, olivacine.
\end{abstract}

Key words 3-aza-olivacine; pyridazino[4,5-b]carbazole; antitumor agent

Olivacine (1,5-dimethyl-6H-pyrido[4,3-b]carbazole) is a member of the pyridocarbazole family of alkaloids. It was first isolated from the bark and stem of Aspidosperma olivaceum $^{2)}$ and it has been found to possess similar antitumor activity as its 5,11-dimethyl isomer, ellipticine, and related compounds like 9-methoxyellipticine. ${ }^{3,4)}$ As the main mechanism of these agents' antineoplastic action, a stabilization of the "cleavable complex" which is formed between DNA and the enzyme, topoisomerase $I I,{ }^{5)}$ is generally accepted, although additional mechanisms have been discussed for some pyridocarbazoles, e.g. reactivation of the lost functionality of the 553 protein. ${ }^{6}$ ) Based on the naturally occurring lead compounds, numerous modifications of this system have been studied, ${ }^{7)}$ leading to the development of drugs like elliptinium, ${ }^{8)}$ datelliptium, ${ }^{9)}$ retelliptine, ${ }^{10)}$ or pazelliptine. ${ }^{11)}$ More recently, the highly potent olivacine analog, S16020$2,{ }^{12,13)}$ has attracted considerable attention due to its apparent ability to circumvent P-glycoprotein-mediated multidrug resistance. $^{14)}$

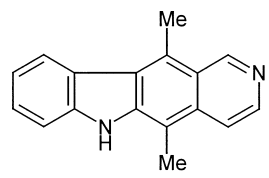

Ellipticine

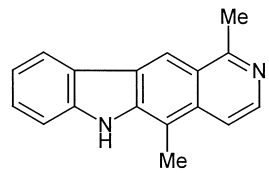

Olivacine
Chart 1

Among the structural variations which have been described so far, there are several examples for incorporation of an additional nitrogen atom into the tetracyclic skeleton, like in the case of 9-aza-ellipticine ${ }^{15)}$ or pazelliptine. ${ }^{11,16)}$ Based on previous investigations in the 3-aza-ellipticine series by Landelle et al., ${ }^{17)}$ we recently reported the synthesis of several pyridazino[4,5- $b]$ carbazoles, some of which exhibited significant antitumor activity. ${ }^{18)}$ In the course of our ongoing research in this field, we now became interested in the synthesis of the hitherto unknown title molecule, 1,5-dimethyl$6 H$-pyridazino[4,5-b]carbazole, as a 3-aza isoster of olivacine, which was required as a reference compound. Until now, only one method for the preparation of 1,5-dialkyl- $6 \mathrm{H}$ pyridazino[4,5- $b]$ carbazoles has been described, which is based on a ring transformation of 5-acyl-11H-pyrido[4,3$a]$ carbazoles under Wolff-Kishner conditions. ${ }^{19)}$ However, this sequence inherently leads to 5-ethyl-substituted pyri- dazino[4,5- $b]$ carbazoles and thus cannot be adopted to the synthesis of our target structure. Here, we wish to report on a short synthesis of 3-aza-olivacine and on the results of an initial in-vitro testing for antitumor activity.

In a first approach to the 1,5-disubstituted pyridazino[4,5$b]$ carbazole skeleton, we investigated the selective addition of methyllithium to an appropriate 1-methylcarbazole-2,3-dicarboxylic acid derivative. After some unsuccessful attempts with the corresponding anhydride, we employed the protected $N$-phenylimide (5) as the electrophile. This compound can be easily prepared starting from commercially available 1-methylpyrano[3,4-b]indol-3(9H)-one ${ }^{20)}$ (1) by Diels-Alder reaction with dimethyl acetylenedicarboxylate which gives the diester (2), ${ }^{20,21)}$ followed by ester hydrolysis and subsequent formation of the cyclic anhydride (3) ${ }^{22)}$ Heating of the latter with excess aniline, followed by protection of the carbazole nitrogen with a benzenesulfonyl group gives $\mathbf{5}$ in good overall yield. For steric reasons, attack of a carbanionic reagent could be expected to take place preferentially at the less hindered $\mathrm{CO}$ group of the cyclic imide structure. Indeed, this was found to be the case: treatment of $\mathbf{5}$ with methyllithium in tetrahydrofuran at $-10^{\circ} \mathrm{C}$ afforded the two acetylcarbazolecarboxamides $\mathbf{6 a}$ and $\mathbf{6 b}$ in a ratio of $1.6: 1$ in favor of the desired isomer $\mathbf{6 a}$; structural assignment is based on nuclear Overhauser enhancement (NOE) difference spectroscopy. Whereas the moderate regioselectivity of this transformation is compensated to some extent by the high combined yield $(90 \%)$, the separation of the two isomers turned out to be very difficult, requiring multiple runs of mediumpressure liquid chromatography. Refluxing of the main product (6a) in hydrazine hydrate for $24 \mathrm{~h}$ smoothly effected the desired pyridazinone ring closure as well as deprotection of the carbazole nitrogen to afford the key intermediate (7a) in high yield. However, in view of the cumbersome $\mathbf{6 a} / \mathbf{6 b}$ separation, we decided to investigate alternative routes to this fused pyridazinone in such a manner that all of the required carbon atoms should be introduced already at the stage of the initial Diels-Alder reaction with the pyrone (1).

Based on findings previously reported by Moody ${ }^{23)}$ who had used similar reagents, we succeeded in transforming the diene $\mathbf{1}$ regiospecifically into the lactone $\mathbf{8}$ in high yield (92\%), using ethyl 4-hydroxy-2-pentynoate as the dienophile in refluxing bromobenzene solution. In order to introduce the required ketone functionality, an attempt was made to selectively brominate the $\mathrm{C} 1$ atom of the fused system in analogy 


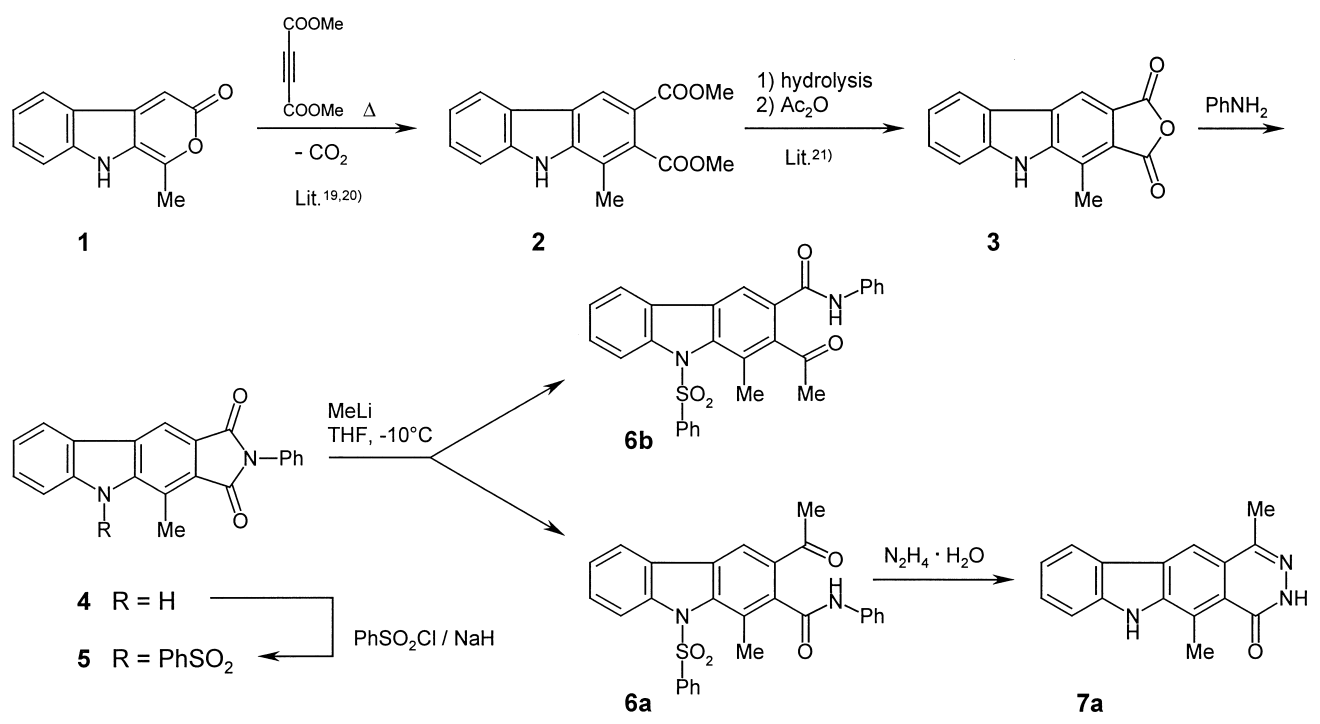

Chart 2

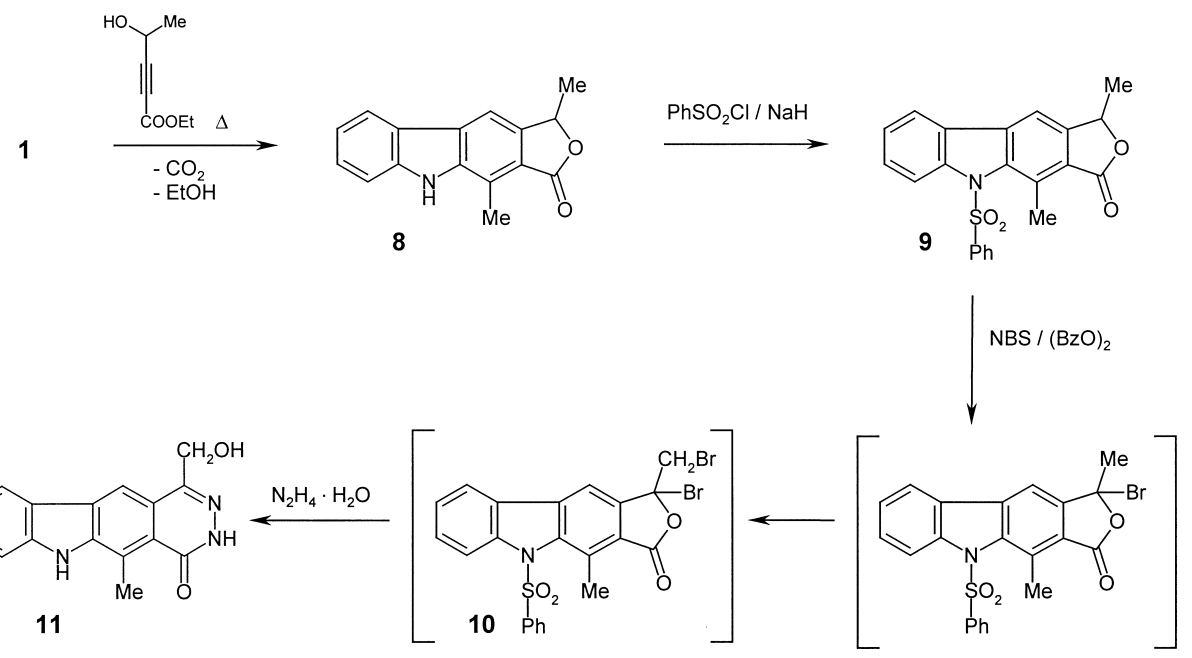

Chart 3

to syntheses of other benzo-fused bromo lactones, ${ }^{24,25)}$ by treatment of $\mathbf{8}$ with $N$-bromosuccinimide (NBS) and dibenzoyl peroxide in refluxing chloroform. However, we were not able to obtain the desired bromo lactone: employment of one equivalent of NBS resulted in the formation of a $1: 1$ mixture of unreacted starting material and a compound which must be a dibrominated derivative. The yield of this dibromo compound for which structure $\mathbf{1 0}$ is proposed ( $c f$. Chart 3) could be raised to about $80 \%$ by increasing the NBS amount to 2.2 eq. Although the unstable dibromo lactone could not be isolated and purified, it could be easily transformed into a stable crystalline product by prolonged refluxing in hydrazine hydrate. Under these conditions, the protecting group is split off and the pyridazinone ring is formed. Interestingly, the latter was found to bear a hydroxymethyl substituent at position 1 .

Although reductive transformation of the $\mathrm{CH}_{2} \mathrm{OH}$ group in 11 into the required methyl substituent could be envisaged, a more direct route to the target structure was sought by a modified pathway which should avoid the need to oxidize any carbon atom. This could be accomplished by employ- ment of ethyl 4-oxo-2-pentynoate as the dienophile in the Diels-Alder reaction with $\mathbf{1}$, however at the expense of an almost complete loss of regioselectivity, which is not surprising in view of previous observations with similar reagents. ${ }^{23)}$ The ratio of the isomeric keto esters $(\mathbf{1 2 a}, \mathbf{b})$ thus formed was determined by ${ }^{1} \mathrm{H}-\mathrm{NMR}$ as $1.2: 1$ in favor of the desired isomer (12a). Whereas the combined yield is very high and the cycloaddition proceeds smoothly within only $2 \mathrm{~h}$ of refluxing in bromobenzene solution, the main problem turned out to be the complete failure to separate the isomers by any means. Moreover, hydrazinolysis of the ester mixture by refluxing in ethanolic hydrazine hydrate for $18 \mathrm{~h}$ expectedly gave the fused pyridazinones $7 \mathbf{a}$ and $\mathbf{7 b}$ in excellent combined yield, but again all attempts failed to separate 7a from its isomer at this stage. However, careful reaction monitoring of this cyclocondensation step by ${ }^{1} \mathrm{H}-\mathrm{NMR}$ revealed that the desired pyridazinone (7a) is formed from its precursor (12a) much faster than the isomer (7b) from the corresponding keto ester (12b). Taking advantage of this kinetic aspect and of the low solubility of the tetracyclic product in the reaction medium, a convenient method for the preparation of pure $\mathbf{7 a}$ 


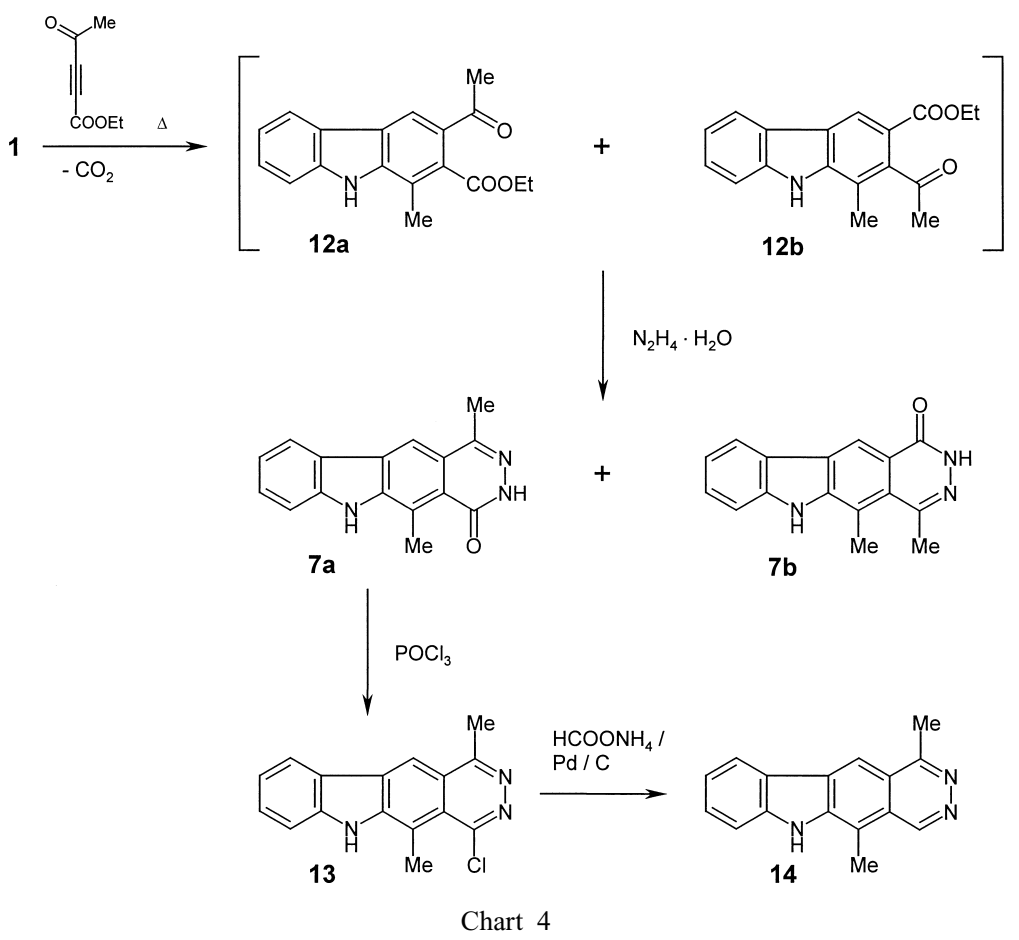

Table 1. Cytotoxic Activity of 3-aza-olivacine (14) and 5-Methyl-6H-pyridazino[4,5-b]carbazole ${ }^{18)}(\mathbf{1 5})$ (\% Inhibition of Cell Growth) at a Fixed Concentration of $3.16 \mu \mathrm{g} / \mathrm{ml}$

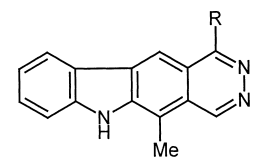

\begin{tabular}{lcccc}
\hline \hline \multirow{2}{*}{ Compound } & \multicolumn{4}{c}{ Cell line $^{a)}$} \\
\cline { 2 - 5 } & KB & L-1210 & SK-OV-3 & MCF-7 \\
\hline $\mathbf{1 4}(\mathrm{R}=\mathrm{Me})$ & 71.2 & 88.2 & 69.5 & 41.9 \\
$\mathbf{1 5}(\mathrm{R}=\mathrm{H})$ & 51.0 & 73.0 & 43.3 & n.d. \\
\hline
\end{tabular}

a) Cell lines: KB, cervical carcinoma; L-1210, lymphatic leukemia; SK-OV-3, ovarian carcinoma; MCF-7, mamma carcinoma. b) Not detectable.

was developed, simply by interrupting the hydrazinolysis process after only $10 \mathrm{~min}$ of refluxing, followed by isolation of the precipitate thus formed (see Experimental). The onepot sequence $\mathbf{1} \rightarrow \mathbf{1 2 a}, \mathbf{b} \rightarrow \mathbf{7} \mathbf{a}$ thus affords the key intermediate in $30 \%$ yield based on the commercially available starting material. After isolation of $\mathbf{7 a}$, refluxing of the remaining reaction mixture was continued for $18 \mathrm{~h}$ to give another precipitate which was found to be a mixture of $7 \mathbf{a}$ and $7 \mathbf{b}$ in a ratio of $0.6: 1$ from which a pure sample of the latter pyridazinone could be isolated by fractional crystallization.

The last two steps to the target compound are straightforward: first, the pyridazinone (7a) was converted into the chloro compound (13) in very good yield by refluxing in phosphorus oxychloride, and finally the chloro substituent was reductively removed by catalytic transfer hydrogenation, using ammonium formate as the hydrogen source. Work-up by continuous extraction with ethyl acetate of an aqueous suspension of the crude product gave analytically pure $\mathbf{1 4}$ in satisfactory yield.
Preliminary evaluation of the cytotoxic activity of 3-azaolivacine (14) towards four human tumor cell lines, using the $\mathrm{XTT}^{26)}$ assay (Table 1), showed significant effects only at a relatively high concentration of $3.16 \mu \mathrm{g} / \mathrm{ml}$ (approx. $10^{-5} \mathrm{M}$ ), whereas at lower concentrations $\left(10^{-6}\right.$ to $\left.10^{-9} \mathrm{M}\right)$ no dose-dependent activity was observed. For all cell lines, growth inhibitory activity of $\mathbf{1 4}$ was found to exceed that of the 5monomethyl congener (15), the synthesis of which we had reported recently. ${ }^{18)}$

In conclusion, a series of $b$-fused carbazoles could be made available, utilizing the Diels-Alder reaction of 1methylpyrano[3,4- $b]$ indol-3(9H)-one (1) with electron-deficient acetylenic dienophiles as the key step. Employment of a 4-oxo-2-pentynoic acid ester in this cycloaddition reaction thus permits the synthesis of the title compound (14) as a new 3-aza bioisoster of the natural product, olivacine, in only four steps from commercially available material. Further structural modifications of this compound type will be carried out, aiming at an enhancement of antineoplastic activity.

\section{Experimental}

Melting points (uncorrected) were determined on a Kofler hot-stage microscope (Reichert). ${ }^{1} \mathrm{H}-\mathrm{NMR}$ spectra were recorded on a Varian UnityPlus 300 spectrometer $(300 \mathrm{MHz})$. IR spectra were recorded on a Perkin-Elmer 1605 FTIR or on a Perkin-Elmer Spectrum 1000 FTIR instrument. Mass spectra were recorded on a Shimadzu QP5050A spectrometer, high-resolution mass spectra were obtained on a Finnigan MAT 8230 instrument at the Institute of Organic Chemistry, University of Vienna, and on a Micromass Autospec instrument at the Department of Organic Chemistry, University of Santiago de Compostela. Elemental analyses were carried out at the Institute of Physical Chemistry (Microanalytical Laboratory), University of Vienna. Column chromatography was performed on Merck Kieselgel 60 (0.063$0.200 \mathrm{~mm}$ ). Medium-pressure liquid chromatography (MPLC) was done on Merck Lobar columns filled with LiChroprep Si $60(0.040-0.063 \mathrm{~mm})$, with UV detection at $280 \mathrm{~nm}$. For TLC, Merck aluminium sheets pre-coated with Kieselgel $60 \mathrm{~F}_{254}$ were used.

Compounds $\mathbf{1},{ }^{20)} \mathbf{2}^{20,21)}$ and $\mathbf{3}^{22)}$ were prepared by known procedures. Solvent names are abbreviated as follows: tetrahydrofuran (THF), $\mathrm{N}, \mathrm{N}$-dimethylformamide (DMF), dimethylsulfoxide (DMSO).

3,5-Dihydro-4-methyl-2-phenylpyrrolo[3,4-b]carbazole-1(2H),3- 
dione $^{27)}$ (4) A mixture of 1-methylcarbazole-2,3-dicarboxylic acid anhydride (3) $(1.0 \mathrm{~g}, 3.98 \mathrm{mmol})$ and aniline $(20 \mathrm{ml})$ was refluxed for $2 \mathrm{~h}$. After cooling, it was poured into ice-water $(50 \mathrm{ml})$. The $\mathrm{pH}$ was adjusted to $1-2$ by addition of concd hydrochloric acid and the product was collected by filtration, washed with water, and dried. Recrystallization from methanol afforded the imide $4(1.17 \mathrm{~g}, 90 \%)$ as colorless crystals, mp $312-313^{\circ} \mathrm{C}$ (lit. ${ }^{27)} \mathrm{mp} 297-298^{\circ} \mathrm{C}$ )

5-Benzenesulfonyl-3,5-dihydro-4-methyl-2-phenylpyrrolo[3,4-b]carbazole-1(2H),3-dione (5) To a stirred, ice-cooled solution of the imide 4 $(2.0 \mathrm{~g}, 6.13 \mathrm{mmol})$ in a $1: 1$ mixture of toluene and DMF $(50 \mathrm{ml})$ was added sodium hydride $(80 \%$ suspension; $0.28 \mathrm{~g}, 9.3 \mathrm{mmol}$ ) in small portions. After $10 \mathrm{~min}$, benzenesulfonyl chloride $(1.42 \mathrm{~g}, 8.04 \mathrm{mmol})$ was added, and the mixture was stirred at room temperature for $4 \mathrm{~h}$. Excess sodium hydride was then decomposed with 7\% sulfuric acid, and the product was extracted with toluene. The extract was washed with water, dried, and evaporated. Recrystallization of the residue from acetonitrile gave compound $5(2.63 \mathrm{~g}, 92 \%)$ as colorless crystals, mp $257-259^{\circ} \mathrm{C} .{ }^{1} \mathrm{H}-\mathrm{NMR}$ (DMSO- $\left.d_{6}\right) \delta: 3.04(3 \mathrm{H}, \mathrm{s}, 4-$ $\left.\mathrm{CH}_{3}\right), 7.20-7.31(4 \mathrm{H}, \mathrm{m}$, phenyl-H), 7.40-7.63 (8H, m, 7- $\mathrm{H}, 8-\mathrm{H}$, phenyl$\mathrm{H}), 8.11(1 \mathrm{H}, \mathrm{d}, J=8.1 \mathrm{~Hz}, 6-\mathrm{H}), 8.16(1 \mathrm{H}, \mathrm{d}, J=7.2 \mathrm{~Hz}, 9-\mathrm{H}$; shows positive NOE on irraditiation at $8.53 \mathrm{ppm}), 8.53(1 \mathrm{H}, \mathrm{s}, 10-\mathrm{H})$. IR $(\mathrm{KBr}) \mathrm{cm}^{-1}: 1762$, $1712,1502,1446,1374,1362,1224,1168,1104,750,692,588$. MS $m / z$ (rel. int.): $466\left(\mathrm{M}^{+}, 10 \%\right), 402$ (4), 326 (29), 325 (82), 297 (12), 242 (20), 178 (19), 123 (38), 95 (20), 77 (100), 51 (34). Anal. Calcd for $\mathrm{C}_{27} \mathrm{H}_{18} \mathrm{~N}_{2} \mathrm{O}_{4} \mathrm{~S} \cdot 0.15 \mathrm{H}_{2} \mathrm{O}: \mathrm{C}, 69.11 ; \mathrm{H}, 3.93 ; \mathrm{N}$, 5.97. Found: $\mathrm{C}, 69.04 ; \mathrm{H}$, $4.15 ; \mathrm{N}, 6.27$.

Reaction of the Imide 5 with Methyllithium A $1.4 \mathrm{M}$ solution of methyllithium in diethyl ether $(1.1 \mathrm{ml}, 1.54 \mathrm{mmol})$ was added dropwise at $-10{ }^{\circ} \mathrm{C}$ to a stirred suspension of the imide $5(620 \mathrm{mg}, 1.33 \mathrm{mmol})$ in dry THF $(40 \mathrm{ml})$ under an atmosphere of nitrogen. The mixture was stirred at $-10{ }^{\circ} \mathrm{C}$ for $30 \mathrm{~min}$ and then at room temperature for $1 \mathrm{~h}$. The volatile components were removed under reduced pressure and the solid residue was prepurified by short-column chromatography (eluent: ethyl acetate/light petroleum, $1: 1$ ). The mixture of the two isomeric products $\mathbf{6 a}$ and $\mathbf{6} \mathbf{b}$ was separated by repeated MPLC with recycling of mixed fractions (eluent: ethyl acetate/light petroleum, $1: 1$ ).

Evaporation of the first fraction afforded $N$-phenyl-3-acetyl-1-methyl-9benzenesulfonyl-9H-carbazole-2-carboxamide (6a) as colorless crystals (360 mg, 55\%), mp $130-131{ }^{\circ} \mathrm{C}$ (ethyl acetate/light petroleum). ${ }^{1} \mathrm{H}-\mathrm{NMR}$ $\left(\mathrm{DMSO}_{-} d_{6}\right) \delta: 1.57\left(3 \mathrm{H}, \mathrm{s}, \mathrm{COCH}_{3}\right), 3.03\left(3 \mathrm{H}, \mathrm{s}, 1-\mathrm{CH}_{3}\right), 6.72(1 \mathrm{H}, \mathrm{s}, \mathrm{NH})$, $7.11-7.15(2 \mathrm{H}, \mathrm{m}$, phenyl-H), $7.22-7.28(2 \mathrm{H}, \mathrm{m}$, phenyl-H), 7.36-7.58 $(8 \mathrm{H}, \mathrm{m}, 6-\mathrm{H}, 7-\mathrm{H}$, phenyl-H), $8.00(1 \mathrm{H}, \mathrm{d}, J=7.8 \mathrm{~Hz}, 5-\mathrm{H}), 8.07(1 \mathrm{H}, \mathrm{d}$, $J=8.1 \mathrm{~Hz}, 8-\mathrm{H}), 8.16(1 \mathrm{H}, \mathrm{s}, 4-\mathrm{H})$. IR $(\mathrm{KBr}) \mathrm{cm}^{-1}: 1700,1676,1496,1368$, 1186, 1172, 770, 756, 576. MS $m / z$ (rel. int.): $482\left(\mathrm{M}^{+}, 1 \%\right), 464$ (9), 400 (6), 341 (7), 326 (10), 324 (24), 323 (100), 308 (30), 293 (11), 191 (7), 77 (34), 51 (15). HR-MS $m / z$ : 482.1301 (Calcd for $\mathrm{C}_{28} \mathrm{H}_{22} \mathrm{~N}_{2} \mathrm{O}_{4} \mathrm{~S}: 482.1300$ ). Anal. Calcd for $\mathrm{C}_{28} \mathrm{H}_{22} \mathrm{~N}_{2} \mathrm{O}_{4} \mathrm{~S} \cdot 0.5 \mathrm{H}_{2} \mathrm{O}: \mathrm{C}, 68.42 ; \mathrm{H}, 4.72 ; \mathrm{N}, 5.70$. Found: C, 68.34; H, 4.93; N, 5.41.

Evaporation of the second fraction gave $N$-phenyl-2-acetyl-1-methyl-9benzenesulfonyl-9H-carbazole-3-carboxamide $(\mathbf{6 b})$ as colorless crystals (225 mg, 35\%), mp 186-188 ${ }^{\circ} \mathrm{C}$ (ethyl acetate/light petroleum). ${ }^{1} \mathrm{H}-\mathrm{NMR}$ $\left(\mathrm{DMSO}_{6}\right) \delta: 1.71\left(3 \mathrm{H}, \mathrm{s}, \mathrm{COCH}_{3}\right), 2.95\left(3 \mathrm{H}, \mathrm{s}, 1-\mathrm{CH}_{3}\right), 6.90(1 \mathrm{H}, \mathrm{s}, \mathrm{NH})$, $7.09-7.13(2 \mathrm{H}, \mathrm{m}$, phenyl-H), 7.22-7.28 (2H, m, phenyl-H), 7.34-7.59 $(8 \mathrm{H}, \mathrm{m}, 6-\mathrm{H}, 7-\mathrm{H}$, phenyl-H), $8.04(1 \mathrm{H}, \mathrm{d}, J=7.8 \mathrm{~Hz}, 5-\mathrm{H}$; shows positive NOE on irraditiation at $8.23 \mathrm{ppm}), 8.07(1 \mathrm{H}, \mathrm{d}, J=8.9 \mathrm{~Hz}, 8-\mathrm{H}), 8.23(1 \mathrm{H}, \mathrm{s}$, 4-H). IR (KBr) cm ${ }^{-1}: 1684,1676,1496,1448,1370,1178,722,688,576$. MS $m / z$ (rel. int.): $482\left(\mathrm{M}^{+}, 6 \%\right), 467$ (8), 464 (10), 400 (16), 399 (13), 326 (20), 324 (26), 323 (100), 308 (29), 293 (35), 249 (16), 147 (14), 77 (64), 51 (25). HR-MS $m / z$ : 482.1310 (Calcd for $\mathrm{C}_{28} \mathrm{H}_{22} \mathrm{~N}_{2} \mathrm{O}_{4} \mathrm{~S}:$ 482.1300). Anal. Calcd for $\mathrm{C}_{28} \mathrm{H}_{22} \mathrm{~N}_{2} \mathrm{O}_{4} \mathrm{~S}$ : C, 69.69; H, 4.60; N, 5.81. Found: C, 69.35; H, $4.71 ; \mathrm{N}, 5.59$.

3,6-Dihydro-1,5-dimethyl-4H-pyridazino[4,5-b]carbazol-4-one (7a) A mixture of compound $\mathbf{6 a}(241 \mathrm{mg}, 0.5 \mathrm{mmol})$ and hydrazine hydrate $(5 \mathrm{ml})$ was refluxed for $24 \mathrm{~h}$. The excess reagent was removed under reduced pressure and the residue was triturated with $1 \mathrm{~m}$ hydrochloric acid $(10 \mathrm{ml})$. The solid was collected by filtration, washed with water, and dried. Recrystallization from ethanol afforded the product $(116 \mathrm{mg}, 88 \%)$ as colorless crystals, mp $312-314^{\circ} \mathrm{C}$ (decomp). ${ }^{1} \mathrm{H}-\mathrm{NMR}$ (DMSO- $\left.d_{6}\right) \delta: 2.62\left(3 \mathrm{H}, \mathrm{s}, 1-\mathrm{CH}_{3}\right)$, $3.16\left(3 \mathrm{H}, \mathrm{s}, 5-\mathrm{CH}_{3}\right), 7.25-7.31(1 \mathrm{H}, \mathrm{m}, 9-\mathrm{H}), 7.52-7.58(1 \mathrm{H}, \mathrm{m}, 8-\mathrm{H})$, $7.61(1 \mathrm{H}, \mathrm{d}, J=8.1 \mathrm{~Hz}, 7-\mathrm{H}), 8.38(1 \mathrm{H}, \mathrm{d}, J=7.8 \mathrm{~Hz}, 10-\mathrm{H}), 8.58(1 \mathrm{H}, \mathrm{s}, 11-$ $\mathrm{H}$; shows positive NOE on irradiation at $2.62 \mathrm{ppm}), 11.71(1 \mathrm{H}, \mathrm{s}$, carbazole$\mathrm{NH}$; shows positive NOE on irradiation at $3.16 \mathrm{ppm}), 11.88(1 \mathrm{H}, \mathrm{s}$, pyridazine-NH). IR (KBr) cm $\mathrm{cm}^{-1}$ : 3415, 3239, 3052, 1642, 1498, 1387, 1364, 1267, 1247, 789, 745, 726. MS $m / z$ (rel. int.): $264(15 \%), 263\left(\mathrm{M}^{+} 100\right), 218$ (5), 204 (4), 163 (4), 132 (3), 91 (12), 84 (7), 72 (7), 71 (13), 55 (11). Anal.
Calcd for $\mathrm{C}_{16} \mathrm{H}_{13} \mathrm{~N}_{3} \mathrm{O}$ : C, 72.99; H, 4.98; N, 15.96. Found: C, 72.65; H, 4.90; N, 15.95 .

1,4-Dimethyl-1,5-dihydro-3H-furo[3,4-b]carbazol-3-one (8) A solution of 1-methylpyrano[3,4- $b]$ indol-3 $(9 H)$-one $(1)(1.0 \mathrm{~g}, 5 \mathrm{mmol})$ and ethyl 4-hydroxy-2-pentynoate $\left.{ }^{28}\right)(1.42 \mathrm{~g}, 10 \mathrm{mmol})$ in bromobenzene $(50 \mathrm{ml})$ was refluxed under argon for $72 \mathrm{~h}$. After cooling, the mixture was diluted with ethyl acetate $(50 \mathrm{ml})$ and filtered through a short column of silica (complete elution with ethyl acetate). The residue obtained on evaporation of the volatile components was recrystallized from toluene to give the lactone 8 ( $1.16 \mathrm{~g}$, $92 \%$ ) as almost colorless crystals, mp $233-234^{\circ} \mathrm{C} .{ }^{1} \mathrm{H}-\mathrm{NMR}$ (DMSO- $d_{6}$ ) $\delta: 1.61\left(3 \mathrm{H}, \mathrm{d}, J=6.6 \mathrm{~Hz}, 1-\mathrm{CH}_{3}\right), 2.86\left(3 \mathrm{H}, \mathrm{s}, 4-\mathrm{CH}_{3}\right), 5.68(1 \mathrm{H}, \mathrm{q}$, $J=6.6 \mathrm{~Hz}, 1-\mathrm{H}), 7.19-7.25(1 \mathrm{H}, \mathrm{m}, 8-\mathrm{H}), 7.46-7.52(1 \mathrm{H}, \mathrm{m}, 7-\mathrm{H}), 7.54$ $7.59(1 \mathrm{H}, \mathrm{m}, 6-\mathrm{H}), 8.16(1 \mathrm{H}, \mathrm{s}, 10-\mathrm{H}$; shows positive NOE on irradiation at $1.61 \mathrm{ppm}), 8.21(1 \mathrm{H}, \mathrm{d}, J=7.8 \mathrm{~Hz}, 9-\mathrm{H}), 11.59(1 \mathrm{H}, \mathrm{s}, \mathrm{NH}) . \mathrm{IR}(\mathrm{KBr}) \mathrm{cm}^{-1}$ : 3289, 3058, 2973, 2926, 1729, 1628, 1511, 1349, 1325, 1306, 1249, 1033, 747. MS $m / z$ (rel. int.): 252 (12\%), $251\left(\mathrm{M}^{+}, 69\right), 237$ (13), 236 (80), 209 (15), 208 (100), 180 (42), 152 (15), 118 (11), 90 (15), 77 (18), 76 (22). Anal. Calcd for $\mathrm{C}_{16} \mathrm{H}_{13} \mathrm{NO}_{2}$ : C, 76.48; H, 5.21; N, 5.57. Found: C, 76.09; H, 5.14; N, 5.48.

5-Benzenesulfonyl-1,4-dimethyl-1,5-dihydro-3 $H$-furo[3,4-b]carbazol3-one (9) To a stirred, ice-cooled solution of the lactone 8 (200 mg, $0.8 \mathrm{mmol})$ in a $1: 1$ mixture of toluene and DMF $(10 \mathrm{ml})$ was added sodium hydride ( $80 \%$ suspension; $45 \mathrm{mg}, 1.5 \mathrm{mmol}$ ) in small portions. After $10 \mathrm{~min}$, benzenesulfonyl chloride $(176 \mathrm{mg}, 1 \mathrm{mmol}$ ) was added and the mixture was stirred at room temperature for $4 \mathrm{~h}$. Excess sodium hydride was then decomposed with 7\% sulfuric acid, and the product was extracted with toluene. The extract was washed with water, dried, and evaporated. Recrystallization of the residue from acetonitrile gave compound $\mathbf{9}(260 \mathrm{mg}, 83 \%)$ as colorless crystals, mp $235-239^{\circ} \mathrm{C} .{ }^{1} \mathrm{H}-\mathrm{NMR}$ (DMSO- $\left.d_{6}\right) \delta: 1.59(3 \mathrm{H}, \mathrm{d}$, $\left.J=6.9 \mathrm{~Hz}, 1-\mathrm{CH}_{3}\right), 2.97\left(3 \mathrm{H}, \mathrm{s}, 4-\mathrm{CH}_{3}\right), 5.68(1 \mathrm{H}, \mathrm{q}, J=6.9 \mathrm{~Hz}, 1-\mathrm{H}), 7.07-$ $7.12(2 \mathrm{H}, \mathrm{m}$, phenyl 2-H, 6- $\mathrm{H}$; shows positive NOE on irradiation at $2.97 \mathrm{ppm}), 7.18-7.24(2 \mathrm{H}, \mathrm{m}$, phenyl $3-\mathrm{H}, 5-\mathrm{H}), 7.39-7.48(2 \mathrm{H}, 8-\mathrm{H}$, phenyl 4-H), 7.55-7.61 (1H, m, 7-H), $7.93(1 \mathrm{H}, \mathrm{d}, J=7.5 \mathrm{~Hz}, 9-\mathrm{H}), 8.04$ $(1 \mathrm{H}, \mathrm{s}, 10-\mathrm{H}), 8.08(1 \mathrm{H}, \mathrm{d}, J=8.4 \mathrm{~Hz}, 6-\mathrm{H}$; shows positive NOE on irradiation at $7.07-7.12 \mathrm{ppm})$. IR $(\mathrm{KBr}) \mathrm{cm}^{-1}$ : 3079, 2975, 2930, 1753, 1448, $1363,1339,1183,1029,772,762,690,576,559$. MS $m / z$ (rel. int.): 391 (13\%), 327 (9), 251 (18), 250 (100), 208 (79), 207 (20), 180 (31), 179 (24), 178 (16), 152 (11), 77 (29), 51 (14). Anal. Calcd for $\mathrm{C}_{22} \mathrm{H}_{17} \mathrm{NO}_{4} \mathrm{~S}: \mathrm{C}, 67.50$; H, 4.38; N, 3.58. Found: C, 67.70; H, 4.47; N, 3.50.

3,6-Dihydro-1-hydroxymethyl-5-methyl-4H-pyridazino[4,5-b]carbazol-4-one (11) A solution of the lactone $9(196 \mathrm{mg}, 0.5 \mathrm{mmol})$ and $N$ bromosuccinimide $(196 \mathrm{mg}, 1.1 \mathrm{mmol})$ in dry chloroform $(10 \mathrm{ml})$ was heated to reflux. Dibenzoyl peroxide $(70 \% ; 10 \mathrm{mg}, 0.03 \mathrm{mmol})$ was added, and refluxing was continued for $3 \mathrm{~h}$. The solvent was evaporated under reduced pressure, the residue of crude dibromo compound $\mathbf{1 0}$ was taken up in hydrazine hydrate $(5 \mathrm{ml})$ and the mixture was refluxed for $18 \mathrm{~h}$. It was then diluted with water $(20 \mathrm{ml})$ and the precipitate was collected by filtration, washed with water, and dried. The material was washed several times with boiling methanol to afford the pure product $(130 \mathrm{mg}, 93 \%)$ as pale yellow crystals, $\mathrm{mp}>320{ }^{\circ} \mathrm{C}$ (decomp). ${ }^{1} \mathrm{H}-\mathrm{NMR}$ (DMSO- $d_{6}$ ) $\delta: 3.16(3 \mathrm{H}, \mathrm{s}, 5-$ $\left.\mathrm{CH}_{3}\right), 4.80\left(2 \mathrm{H}, \mathrm{d}, J=5.7 \mathrm{~Hz}, \mathrm{C}_{2} \mathrm{OH}\right), 5.43\left(1 \mathrm{H}, \mathrm{t}, J=5.7 \mathrm{~Hz}, \mathrm{CH}_{2} \mathrm{O} \underline{\mathrm{H}}\right)$, $7.25-7.31(1 \mathrm{H}, \mathrm{m}, 9-\mathrm{H}), 7.52-7.58(1 \mathrm{H}, \mathrm{m}, 8-\mathrm{H}), 7.62(1 \mathrm{H}, \mathrm{d}, J=8.1 \mathrm{~Hz}$, $7-\mathrm{H}), 8.29(1 \mathrm{H}, \mathrm{d}, J=7.8 \mathrm{~Hz}, 10-\mathrm{H}), 8.73(1 \mathrm{H}, \mathrm{s}, 11-\mathrm{H}$; shows positive NOE on irradiation at $4.80 \mathrm{ppm}), 11.72(1 \mathrm{H}, \mathrm{s}$, carbazole $\mathrm{NH}$; shows positive NOE on irradiation at $3.16 \mathrm{ppm}), 12.00(1 \mathrm{H}, \mathrm{s}$, pyridazine $\mathrm{NH})$. IR $(\mathrm{KBr})$ $\mathrm{cm}^{-1}: 3415,3335,3251,3062,2926,1627,1495,1453,1417,1376,1337$, $1239,1026,822,768,754$. MS $m / z$ (rel. int.): $280(18 \%), 279\left(\mathrm{M}^{+}, 100\right)$, 278 (21), 263 (15), 250 (40), 233 (24), 205 (20), 192 (11), 164 (8), 140 (12), 102 (19), 98 (18), 88 (12), 81 (28). Anal. Calcd for $\mathrm{C}_{16} \mathrm{H}_{13} \mathrm{~N}_{3} \mathrm{O}_{2}: \mathrm{C}, 68.81$; H, 4.69; N, 15.04. Found: C, 68.53; H, 4.77; N, 15.21 .

One-Pot Synthesis of the Pyridazinones $7 \mathrm{a}$ and $7 \mathrm{~b}$ from the Pyranoindole 1 A solution of 1-methylpyrano[3,4-b]indol-3(9H)-one (1) (398 mg, $2 \mathrm{mmol}$ ) and ethyl 4-oxo-2-pentynoate ${ }^{29)}(560 \mathrm{mg}, 4 \mathrm{mmol})$ in bromobenzene $(30 \mathrm{ml})$ was refluxed under argon for $2 \mathrm{~h}$. The volatile components were removed under reduced pressure and the oily residue consisting of the two isomeric esters 12a and 12b was dissolved in ethanol $(8 \mathrm{ml})$. After addition of hydrazine hydrate $(300 \mathrm{mg}, 6 \mathrm{mmol})$, the solution was refluxed for $10 \mathrm{~min}$, then it was immediately chilled. The precipitate was collected by filtration, washed with ethanol, and dried to afford pure $7 \mathbf{a}(160 \mathrm{mg}, 30 \%)$. The filtrate was refluxed for another $18 \mathrm{~h}$. The precipitate thus obtained was filtered off, washed with ethanol, and dried to afford a mixture of $7 \mathbf{a}$ and $7 \mathbf{b}(225 \mathrm{mg}$, $43 \%$ ) in a ratio of $0.6: 1$. Fractional crystallization from ethanol gave pure 2,6-dihydro-4,5-dimethyl-1 $H$-pyridazino[4,5-b]carbazol-1-one (7b) as colorless crystals, mp $>350{ }^{\circ} \mathrm{C}$ (decomp). ${ }^{1} \mathrm{H}-\mathrm{NMR}$ (DMSO- $\left.d_{6}\right) \delta: 2.79(3 \mathrm{H}, \mathrm{s}$, 
4- $\mathrm{CH}_{3}$; shows positive NOE on irradiation at $\left.2.99 \mathrm{ppm}\right), 2.99\left(3 \mathrm{H}, \mathrm{s}, 5-\mathrm{CH}_{3}\right)$, $7.23-7.29(1 \mathrm{H}, \mathrm{m}, 9-\mathrm{H}), 7.50-7.56(1 \mathrm{H}, \mathrm{m}, 8-\mathrm{H}), 7.60(1 \mathrm{H}, \mathrm{d}, J=8.1 \mathrm{~Hz}$, 7-H), $8.34(1 \mathrm{H}, \mathrm{d}, J=7.8 \mathrm{~Hz}, 10-\mathrm{H}), 8.99(1 \mathrm{H}, \mathrm{s}, 11-\mathrm{H}), 11.69(1 \mathrm{H}, \mathrm{s}$, carbazole NH; shows positive NOE on irradiation at $2.99 \mathrm{ppm}), 12.13(1 \mathrm{H}, \mathrm{s}$, pyridazine $\mathrm{NH})$. IR (KBr) cm $\mathrm{cm}^{-1}: 3284,3064,2987,1642,1625,1603,1551$, $1455,1386,1353,1293,1234,1176,795,742,731,557$. MS $m / z$ (rel. int.): 264 (18\%), 263 (100), 234 (19), 219 (11), 218 (26), 206 (20), 205 (12), 204 (22), 191 (15), 102 (11), 88 (8). HR-MS m/z: 263.1071 (Calcd for $\mathrm{C}_{16} \mathrm{H}_{13} \mathrm{~N}_{3} \mathrm{O}$ : 263.1059). Anal. Calcd for $\mathrm{C}_{16} \mathrm{H}_{13} \mathrm{~N}_{3} \mathrm{O} \cdot 0.1 \mathrm{H}_{2} \mathrm{O}: \mathrm{C}, 72.49 ; \mathrm{H}$, $5.02 ; \mathrm{N}, 15.85$. Found: C, 72.46; H, 4.81; N, 15.88 .

4-Chloro-1,5-dimethyl-6H-pyridazino[4,5-b]carbazole (13) A mixture of the pyridazinone $7 \mathbf{a}(263 \mathrm{mg}, 1 \mathrm{mmol})$ and $\mathrm{POCl}_{3}(25 \mathrm{ml})$ was refluxed for $3 \mathrm{~h}$. The excess reagent was distilled off under reduced pressure and the residue was treated with crushed ice $(20 \mathrm{~g})$. The mixture was basified by addition of concd ammonia and the precipitate was collected by filtration, washed with water, and dried to afford the product $(260 \mathrm{mg}, 92 \%)$ as a yellow solid, $\mathrm{mp}>300{ }^{\circ} \mathrm{C}$ (decomp). ${ }^{1} \mathrm{H}-\mathrm{NMR}$ (DMSO- $\left.d_{6}\right) \delta$ : $3.01(3 \mathrm{H}, \mathrm{s}$, 1- $\left.\mathrm{CH}_{3}\right), 3.20\left(3 \mathrm{H}, \mathrm{s}, 5-\mathrm{CH}_{3}\right), 7.31-7.37(1 \mathrm{H}, \mathrm{m}, 9-\mathrm{H}), 7.59-7.67(2 \mathrm{H}, \mathrm{m}$, 7-H, 8-H), $8.49(1 \mathrm{H}, \mathrm{d}, J=8.1 \mathrm{~Hz}, 10-\mathrm{H}), 9.02(1 \mathrm{H}, \mathrm{s}, 11-\mathrm{H}$; shows positive NOE on irradiation at $3.01 \mathrm{ppm})$. IR $(\mathrm{KBr}) \mathrm{cm}^{-1}: 3236,3063,2922,1627$, $1609,1496,1467,1400,1360,1310,1260,745,591$. MS $m / z$ (rel. int.): 283 $\left(\mathrm{M}^{+}, 4 \%\right), 281\left(\mathrm{M}^{+}, 10\right), 264$ (18), 263 (100), 246 (7), 234 (9), 218 (15), 204 (13), 191 (10), 132 (11), 121 (16), 109 (14), 102 (22), 95 (22), 91 (15), 83 (16), 57 (29), 55 (29). HR-MS m/z: 281.0712 (Calcd for $\mathrm{C}_{16} \mathrm{H}_{12} \mathrm{ClN}_{3}$ : 281.0720). Anal. Calcd for $\mathrm{C}_{16} \mathrm{H}_{12} \mathrm{ClN}_{3} \cdot 0.6 \mathrm{H}_{2} \mathrm{O}: \mathrm{C}, 65.69 ; \mathrm{H}, 4.55 ; \mathrm{N}$, 14.36. Found: C, 65.56; H, 4.29; N, 14.50 .

1,5-Dimethyl-6H-pyridazino[4,5-b]carbazole (14) A mixture of the chloro compound $13(281 \mathrm{mg}, 1 \mathrm{mmol})$, ammonium formate $(630 \mathrm{mg}$, $10 \mathrm{mmol})$, and $10 \% \mathrm{Pd} / \mathrm{C}$ catalyst $(60 \mathrm{mg})$ in methanol $(60 \mathrm{ml})$ was refluxed under argon for $1 \mathrm{~h}$. After addition of another portion of ammonium formate ( $315 \mathrm{mg}, 5 \mathrm{mmol}$ ), refluxing was continued for $2 \mathrm{~h}$. The catalyst was filtered off and the filtrate was evaporated under reduced pressure. The residue was taken up in water $(200 \mathrm{ml})$ and the mixture was basified by addition of concd ammonia $(2 \mathrm{ml})$. The suspension was continuously extracted with ethyl acetate $(400 \mathrm{ml})$ for $24 \mathrm{~h}$, using a rotary perforator. The extract was kept in the refrigerator for $16 \mathrm{~h}$, then the separated solid was collected by filtration, washed with cold ethyl acetate, and dried to afford the pure product $(150 \mathrm{mg}$, $61 \%$ ) as pale yellow crystals, $\mathrm{mp}>340{ }^{\circ} \mathrm{C}$ (decomp). ${ }^{1} \mathrm{H}-\mathrm{NMR}$ (DMSO- $d_{6}$ ) $\delta: 2.95\left(3 \mathrm{H}, \mathrm{s}, 5-\mathrm{CH}_{3}\right.$; shows positive NOE on irradiation at $\left.9.73 \mathrm{ppm}\right), 3.03$ $\left(3 \mathrm{H}, \mathrm{s}, 1-\mathrm{CH}_{3}\right.$; shows positive $\mathrm{NOE}$ on irradiation at $\left.8.92 \mathrm{ppm}\right), 7.27-7.33$ $(1 \mathrm{H}, \mathrm{m}, 9-\mathrm{H}), 7.55-7.64(2 \mathrm{H}, \mathrm{m}, 7-\mathrm{H}, 8-\mathrm{H}), 8.45(1 \mathrm{H}, \mathrm{d}, J=7.8 \mathrm{~Hz}, 10-\mathrm{H})$, $8.92(1 \mathrm{H}, \mathrm{s}, 11-\mathrm{H}), 9.73(1 \mathrm{H}, \mathrm{s}, 4-\mathrm{H}), 11.75(1 \mathrm{H}, \mathrm{s}, \mathrm{NH}) . \mathrm{IR}(\mathrm{KBr}) \mathrm{cm}^{-1}$ : 3059, 2924, 2874, 2765, 1611, 1498, 1467, 1416, 1401, 1379, 1315, 1253, 1228, 865, 745, 590, 554. MS m/z (rel. int.): 248 (20\%), 247 ( $\left.\mathrm{M}^{+}, 100\right), 246$ (17), 219 (14), 205 (13), 189 (51), 178 (10), 151 (13), 134 (17), 124 (11), 109 (20), 102 (24), 96 (21), 94 (23), 88 (14), 82 (16), 70 (20). Anal. Calcd for $\mathrm{C}_{16} \mathrm{H}_{13} \mathrm{~N}_{3}$ : C, 77.71; H, 5.30; N, 16.99. Found: C, 77.57; H, 5.43; N, 17.02 .

Acknowledgements The authors are grateful to Zentaris AG, Frankfurt/Germany, for performing the in-vitro evaluation of antitumor activity. E. S. wishes to thank the University of Santiago de Compostela and the Austrian Academic Exchange Service for support of his postdoctoral stay at the University of Vienna. Experimental contributions by Mr. J. A. Maasai are gratefully acknowledged.

\section{References and Notes}

1) Present address: Department of Organic Chemistry, Laboratory of Medicinal Chemistry, University of Santiago de Compostela, 15782
Santiago de Compostela, Spain.

2) Schmutz J., Hunziker F., Pharm. Acta Helv., 33, 341-347 (1958).

3) Mosher C. W., Crews O. P., Action E. M., Goodman L., J. Med. Chem., 9, 237-241 (1966).

4) Gribble G. W., "The Alkaloids," Vol. 39, ed. by Brossi A., Academic Press, New York, 1990, pp. 239-352.

5) Tewey K. M., Chen G. L., Nelson E. M., Liu L. F., J. Biol. Chem., 259, 9182-9187 (1984).

6) Ohashi M., Sugikawa E., Nakanishi N., Jpn. J. Cancer Res., 86, 819827 (1995).

7) Ohashi M., Oki T., Expert Opin. Ther. Pat., 6, 1285-1294 (1996).

8) Le Pecq J. B., Paoletti C., Nguyen Dat X., DE 2618223 (1976) [Chem. Abstr., 86, 55620 (1977)].

9) Le Pecq J. B., Paoletti C., US 4310667 (1982) [Chem. Abstr., 96, 181489 (1982)].

10) Bisagni E., Ducrocq C., Rivalle C., Tambourin P., Wendling F., Civier A., Montagnier L., Chermann J. C., Gruest J., Lidereau R., EP 10029 (1980) [Chem. Abstr., 94, 30988 (1981)].

11) Bisagni E., Ducrocq C., Rivalle C., Tambourin P., Wendling F., Chermann J. C., Montagnier L., DE 2815724 (1978) [Chem. Abstr., 90, 87427 (1979)]

12) Guillonneau C., Pierré A., Charton Y., Guilbaud N., Kraus-Berthier L., Léonce S., Michel A., Bisagni E., Atassi G., J. Med. Chem., 42, 2191-2203 (1999).

13) Le Mée S., Pierré A., Markovits J., Atassi G., Jacquemin-Sablon A., Saucier J.-M., Mol. Pharmacol., 53, 213-220 (1998).

14) Pierré A., Léonce S., Pérez V., Atassi G., Cancer Chemother. Pharmacol., 42, 454-460 (1998).

15) Rivalle C., Ducrocq C., Bisagni E., J. Chem. Soc., Perkin Trans. 1, 1979, 138-141 (1979).

16) Ducrocq C., Bisagni E., Rivalle C., Lhoste J. M., J. Chem. Soc., Perkin Trans. 1, 1979, 142-145 (1979).

17) Landelle H., Laduree D., Cugnon de Sevricourt M., Robba M., Chem. Pharm. Bull., 37, 2679-2682 (1989).

18) Haider N., Jbara R., Khadami F., Wanko R., Heterocycles, 48, 16091622 (1998).

19) Baradarani M. M., Joule J. A., J. Chem. Soc., Chem. Commun., 1978, 309-310 (1978).

20) Plieninger H., Müller W., Weinerth K., Chem. Ber., 97, 667-681 (1964).

21) Moody C. J., J. Chem. Soc., Perkin Trans. 1, 1985, 2505-2508 (1985).

22) Lancelot J. C., Landelle H., Robba M., Chem. Pharm. Bull., 32, 902908 (1984).

23) Moody C. J., Shah P., J. Chem. Soc., Perkin Trans. 1, 1988, 14071415 (1988)

24) Sugimoto A., Tanaka H., Eguchi Y., Ito S., Takashima Y., Ishikawa M., J. Med. Chem., 27, 1300-1305 (1984).

25) Neudeck H. K., Monatsh. Chem., 127, 201-217 (1996).

26) Scudiero D. A., Shoemaker R. H., Paull K. D., Monks A., Tierney S., Nofziger T. H., Currens M. J., Seniff D., Boyd M. R., Cancer Res., 48, 4827-4833 (1988)

27) Pindur U., Haber M., Erfanian-Abdoust H., Heterocycles, 34, 781790 (1992).

28) Herrmann J. L., Berger M. H., Schlessinger R. H., J. Am. Chem. Soc., 101, 1544-1549 (1979).

29) Yerino L. V., Osborn M. E., Mariano P. S., Tetrahedron, 38, 1579$1591(1982)$ 